\title{
Isolating mechanisms as sustainability factors of resource-based competitive advantage
}

Professor Karolina Mazur University of Zielona Góra Zdzisław Kulczyk, M.A. W.P.P.H.U. AXA

\section{Introduction}

There is a growing role of value in contemporary literature concerned with strategic management. Two major problems are the objects of consideration. The first problem is value creation and academics have been studying it for more than twenty years (for example: Porter 1990, Stabell \& Fjeldstad 1998, Bowman \& Ambrosini 2000). Recently there has been a growing attention paid to the problem of value appropriation (or capture) (Bowman and Ambrosini 2000, Bryler and Coff 2003, Hurmelinna-Laukkanen \& Puumalainen 2007). The growing interest in networks, where competition and co-opetition are the source of challenge for entrepreneurs: how to appropriate the value from their activity. Moreover, there is a growing significance of Resource Based View, where the problem of rent appropriation is crucial. But value appropriation is more universal problem and cannnot be considered only in networked business. The problem of appropriation can have also a long-term dimension. The main problem is not to share current profits but to retain for long-term ability to earn more than 
competitors. This protection of a long-term competitive advantage can be a more complicated problem than the protection of current profits.

In the Resource Based View there appears a problem of value appropriation. There are two approaches to value appropriation in the current literature:

1. A short-term appropriation of current gains by particular partners and other stakeholders based on bargaining power and appropriability regime (Madhok et al. 2010, Coff 2010, 2003, 1999, Chacar \& Coff 2000, Hurmelinna-Laukkanen \&Puumalainen 2007).

2. Aong-term approach, where appropriation is referred to competitors attempting to copy the ability of generating excess rent (Dehning \& Stratopoulos, 2003, Rumelt 1984).

The first approach found a group of proponents. They are focused on approprability regimes (Hurmelinna-Laukkanen \& Puumalainen 2007). Whereas/However methods of value retention by strengthening strategic character of resources can be identified as isolating mechanisms (Rumelt 1984) or sustainability factors (Dehning \& Stratopoulos, 2003). Usually they refer to the problem of competitive advantage in diversified approaches, but they have special meaning in Resource Based View. In this approach the subject of isolation is the ability to abnormal profits from strategic resource. This strategic resource fulfills the conditions of VRIO (Value, Rareness, Immitability and Non-substitutability) (Barney 1991, Barney \&Clark 2007). This valuable resources have often their strategic nature only temporary. The sustainability of the competitive advantage bases on factors preserving competitors from copying. That is why the concept of isolating mechanisms is comparable to barriers of entry.

In the business practice strategic resources operate in seclusion. Usually they combine with other resources - strategic or generic (which have not attributes of strategic) (Barney 1991). Therefore although the point of entry can be the analysis of strategic resources, finally the main problem of a strategist is to achieve certain isolating mechanism referred to the set of resources. But in the case, when strategic resource combines with generic one, isolating mechanism is referred only to strategic resource (figure 1).

The process of resource integration causes finally that:

- there is no possibility to state which part of the value is generated by certain resource and which comes from the exploitation of resource set,

- there is no possibility to state, which particular mechanism prevents particular resource from copying (sustainability factor) and by doing so protects retained value for a long term. 


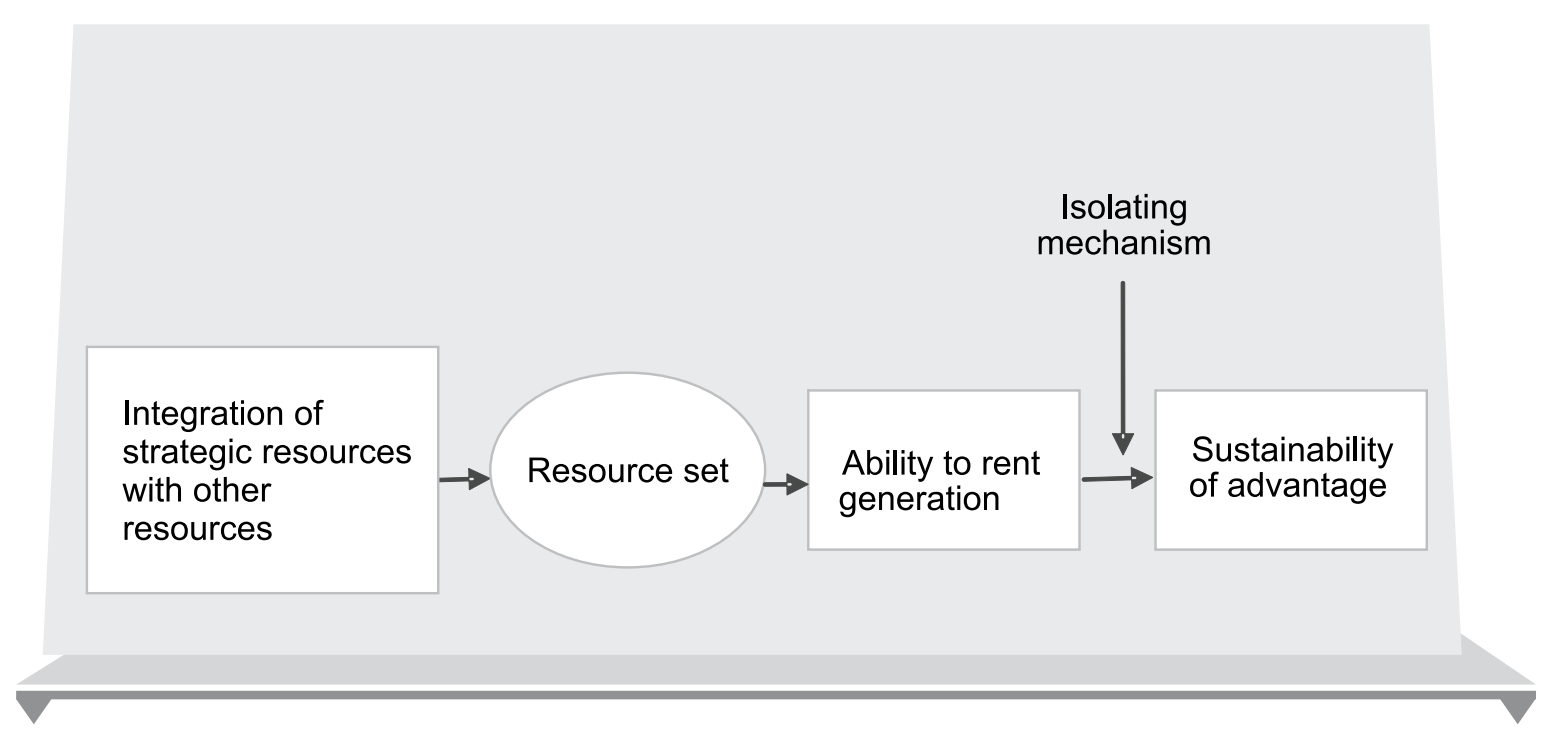

Figure 1. The adavantage creation from resource set

Source: own elaboration

Isolating mechanisms allow the resource owner value appropriation. It also allows resources protection from copying and (in the long time) possibility for protection from value captured by competitors. Each mechanism can exploit techniques and interventions which are named by authors as isolating tools. Because of editorial limitations, the analysis of isolating tools for particular mechanisms was postponed to the next paper.

The creation of resource set, where each resource can be protected by a distinct mechanism becomes a reason for the appearance of causal ambiguity. This ambiguity protects resources from copying and is one of basic isolating mechanisms. This is an important mechanism but what are other types? Are they identified in the literature?

The aim of this paper is the identification of categories of isolating mechanisms presented in the literature and the appraisal if current systems of categorization are sufficient. To achieve this goal there is presented a critical analysis of literature. To support the result there is an analysis of the case. A small business with appropriate historical perspective has been selected for this task. It enabled authors to identify the sources of strategic advantage and how sustainable it was. The case was presented only in a range allowing authors to identify the mechanisms because of editors restrictions. 


\section{The essence ant types of isolating mechanisms}

As it was mentioned before, "An isolating mechanism is any knowledge, physical, or legal barrier that may prevent replication of the value-creating new task, product, or service by a competitor" (Lepak, Smith \& Taylor 2007 p.188, Rumelt 1987). Moreover, such mechanisms play a significant strategic role: they allow to keep a long-term competitive advantage, which is the ability of firm to generate resource rent (abnormal profits). The question is not only how to share current profits, but how to keep the long-term ability of extraordinary profits (which are understood as strategic resource rent). Isolating mechanisms generate such ability.

The nature of isolating mechanisms can be diversified on different levels of analysis (Lepak, Smith \& Taylor 2007, p. 188). According to D.P. Lepak et alliances, on the individual level there are many attributes than can be used as isolating mechanisms. R.S. Burt (1992) gives an example of the position of the individual in a social network. D. P. Lepak et alliances (2007, p. 188) mentioned also the relationship with co-workers, specialized and tacit knowledge gained by professional experience.

On the organizational level, the isolating mechanism can be concerned with the presence of strategic resources (Lepak at al. 2007, s. 189).These authors refer to J. Barney, who expressed such opinion in 1991. However D.G. Sirmon el al. (2007) indicated the process of resorce management as crucial isolating mechanism. They presented also some recommendations for this process. According to them, organizations should (Sirmon et al. 2007, p. 289):

- „effectively structure the firm's resource portfolio,

- bundle resources into valuable capabilities,

- and formulate leveraging strategies that exploit the firm's capabilities to create value for customers".

D. P. Lepak et alliances for the analysis of isolating mechanisms reffered to M.E Porter (1990), who postulated that nations will retain value which they created if they have a unique advantage based on resources or other factors, advantageous demand conditions, appropriate infrastructure and competitive markets (Lepak 2007).

Later A. Madhok et al. defined two basic types of isolating mechanism (Madhok 2010):

- WIM -willingness isolating mechanisms - resource exploiting is too costly and competitors are not willing to undertake this task,

- AIM -ability based mechanisms - based on the assumption that competitors have no ability to imitate the resource. 
Willingness isolating mechanisms result from the fact that acceding to business process generates high alternative costs. It is concerned with the theory of comparative firm advantage (CFA). Whereas/ However ability based isolating mechanisms means limitations which is caused by limited access to the resource (tangible or intangible), which is impossible for imitation and such mechanisms are referred to Resource Based View (Madhok et al. 2010).

In $2012 \mathrm{~J}-\mathrm{H}$. Lim and alliances identified two isolating mechanisms. The first of them was causal ambiguity, which is referred to the assumption that there can be illegible for competitors causality between resource and market success (Rumelt 1987). V. Ambrosini and C. Bowman (2010) on the basis of the work of A.W. King and C.P. Zeithaml (2001) identified additionally two types of such ambiguity: linkage ambiguity - inability to recognize relationship, and inherent ambiguity - concerned with resource itself. Beside causal ambiguity, J-H. Lim and alliances identified a second mechanism: path dependency, which comes from the fact, that decisions made in early stage of business or project significantly influence current choices and results (Lim et al. 2012).

These authors refer to the prior work of B. Dehning and T. Stratopoulos (2003), who listed 6 sustainability factors of resource based competitive advantage referred to different economic and managerial concepts. Beyond causal ambiguity and path dependence they listed 4 mechanisms. The first was lead time - concerned with the theory that there exists a set of factors which determine time from project (or business) start to real competitors response. The second was the role of history, referred to unique historical conditions, which enabled a firm to reach or develop resources (for example: there was an occasion to acquire the resource with low cost but later competitors had no such a chance and had no advantage). The third mechanism based on socially complex links social factors, which are behind firm control in a systematic way, which induces difficulties in resource imitation. The fourth mechanism results from time compression diseconomies and refers to the problem of time consuming process of resource imitation. Amongst 6 of these mechanisms only the last one is a WIM type.

Another system of categorization was presented by S.B. Bach et al. in 2008, however only in context of IPO (Iitial Public Offering), which makes this system to particular to use in generalization and inadequate for RBV analysis.

In 2007 P. Hurmelinna-Laukkanen and K. Puumalainen presented a concept of appropriation regime based on appropriation mechanisms. Such mechanisms were divided into three basic groups: group resulted from availability, group resulted from efficacy and group resulted from efficiency. 
All of these groups were divided for external and internal factors. External factors of availability and efficacy named primary and internal factors of availability and efficacy named secondary. Conversely internal factors of efficiency named primary and external factors of efficiency named secondary. According to authors, there exist many factors, which allow to include appropriation mechanisms to the regime. One of them is being in firm disposal. Moreover, they said that there are certain abilities of particular mechanisms to create temporary monopoly on the market (Hurmelinna-Laukkanen \& Puumalainen 2007, p. 5). The example of primary mechanism based on availability can be market peculiarity and this is an external factor. The internal factor can be a knowledge specificity in organization. The example of primary (external) mechanism of appropriation in area of efficacy can be legal rights protection. The example of primary (internal) factor based on efficiency can be strategy exploiting bergaining power, whereas an example of secondary (external) can be a potential to implement market strategy (HurmelinnaLaukkanen \& Puumalainen 2007, p. 6). Finally, authors llisted a few sources of such mechanisms: the nature of knowledge (tacit or explicit), legal protection, human resource management, technical and practical means and lead time (Hurmelinna-Laukkanen \& Puumalainen 2007, p. 98). Such mechanisms can refer to current rent appropriation and to long-term advantage protection. The interests of authors focus on intangible resources and knowledge based economy.

D. P. Lepak et al. in 2007 presented the concept that isolating mechanisms can be considered on three levels: individual, organizational and social (national) and these levels determine the type of mechanism. Because of the organizational context of these considerations, authors naturally focus on organizational level. On this level the isolating mechanism can be (according to D.P. Lepak and al., p. 189) the existence (or coexistence) of strategic resources. Authors refer to J. Barney concept from 1991. Whereas D. G. Sirmon and al. (2007) indicated the process of resource management as a key isolating mechanism. That is why, sometimes isolating mechanisms on the organizational level should be analyzed in the context of co-existing resources, which are intentionally integrated and generate bundles. Combining strategic and generic resources allows to create the resource of some special properties (Mazur 2011, p. 81). In many cases, the existence of ....(of what?) does not generate advantage but only a combined resource has such power. That is why, in the organizational context, mechanism should be analyzed for resource bundle. 


\section{Isolating mechanisms for the analyzed case}

For exemplification of presented concepts authors used the case of an ice-cream producer, which was a micro firm. This venture was simple enough to enable authors to distinguish strategic resources and isolating mechanisms. Moreover, it passed more than 20 years from business start and it allows for the assessment of the range of competitive advantage and its sustainability. Figure 2 presents the procedure of the analysis.

According to the analysis procedure authors asked two research questions (Czakon 2011, p. 54):

1. Which mechanisms referred to the literature presented above enabled the firm to sustain the advantage for 10 years?

2. Is the list of mechanism categories complete?

The tool of data gathering was an interview with the entrepreneur. Because of historical conditions and editorial requirements for this journal, very particular data was omitted (including financial and organizational data).

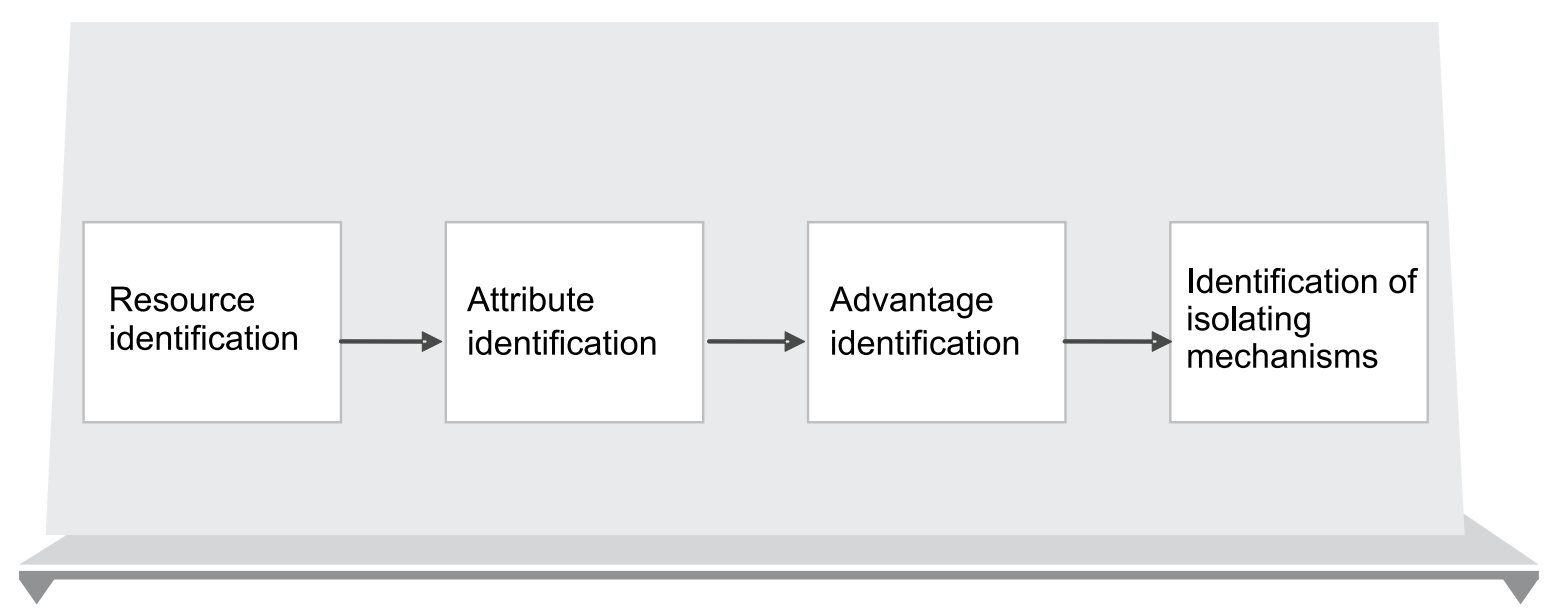

Figure 2. Steps of analysis

Source: own elaboration

In 1990 the entrepreneur started the business - production and sales of icecream. The entrepreneur acquired on the secondary market a machine which had non-standard parameters. Before the start of production the entrepreneur installed an additional system of chilling, which doubled the capacity of this machine. This innovation was not patented and it preserved it from copying. 
To start a small business, the entrepreneur received a loan in a bank, which was granted for preferred conditions (only temporary, for people in special age and education).

The entrepreneur owned also a summer cafe with overhead protection, which was made by an artist-constructor from the USSR. In the same time the entrepreneur regenerated the relation with a friend, who had experience in running the enterprise and in ice-cream production. He transferred to the entrepreneur the recipe which raised a quality of ice-cream and finally allowed the entrepreneur to sell $200 \%$ more than competitors.

The entrepreneur employed three retired persons, who were thankful for employment and were very loyal. Only two persons (main salesman and purchasing officer) and the entrepreneur had access to the recipe. Young students selling ice-cream (6 persons) received a ready mixture for ice-cream production and they did not have knowledge about the recipe.

The entrepreneur had consciousness and intuition. He predicted a change on the market and quitted the business one year before the entrance of supermarkets offering ice-cream with competing recipes.

The producing machine was sold for a good price at the end of the boom for small business to an entrepreneur from a large town. The firm conducted a diversified activity in this time, assets enhanced other activities.

During the analysis there were identified following strategic resources:

(1) Information about possibility of machine purchase.

(2) Innovation - additional chilling system.

(3) Bank loan - preferential conditions.

(4) The area of specific localization.

(5) Relations with mentor.

(6) Unique technological knowledge.

(7) Employee loyalty.

The table 1 includes systems of categorization and reference to the analyzed case. 
Table 1. Types of isolating mechanisms

\begin{tabular}{|c|c|c|c|}
\hline Authors & $\begin{array}{c}\text { Types of } \\
\text { mechanisms }\end{array}$ & $\begin{array}{l}\text { Mechanism } \\
\text { characteristics }\end{array}$ & Reference to the case -example \\
\hline 1 & 2 & 3 & 4 \\
\hline \multirow[t]{2}{*}{$\begin{array}{l}\text { Madhok, Li, } \\
\text { Priem } 2010\end{array}$} & $\begin{array}{l}\text { WIM - } \\
\text { willingness- } \\
\text { based isolating } \\
\text { mechanisms }\end{array}$ & $\begin{array}{l}\text { Limitations resulted } \\
\text { from the alternative } \\
\text { cost generated by } \\
\text { copying the resource }\end{array}$ & $\begin{array}{l}\text { The recipe was possible for } \\
\text { recognition but after long time of the } \\
\text { research which refrained competitors } \\
\text { from doing it }\end{array}$ \\
\hline & $\begin{array}{l}\text { AIM - ability } \\
\text { based isolating } \\
\text { mechanisms }\end{array}$ & $\begin{array}{l}\text { Limitations resulted } \\
\text { from the ability of } \\
\text { competitors of copying } \\
\text { the resource }\end{array}$ & $\begin{array}{l}\text { The relationship with mentor and his } \\
\text { knowledge was a strategic resource, } \\
\text { this resource was protected by } \\
\text { socially complex links, which could } \\
\text { not be recognized and created }\end{array}$ \\
\hline \multirow[t]{2}{*}{ Lim 2012} & Causal ambiguity & $\begin{array}{l}\text { Mechanism based on } \\
\text { causal ambiguity - } \\
\text { competitors do not } \\
\text { know, what are the } \\
\text { logical links between } \\
\text { the resource and } \\
\text { abnormal profits }\end{array}$ & $\begin{array}{l}\text { Nobody understands why the } \\
\text { efficiency of the machine is so high } \\
\text { and entrepreneur earns such income }\end{array}$ \\
\hline & Path dependency & $\begin{array}{l}\text { Mechanism which } \\
\text { leads to sustainable } \\
\text { heterogeneity of } \\
\text { organizational } \\
\text { capabilities referred to } \\
\text { IT (ITC) }\end{array}$ & $\begin{array}{l}\text { The decision about flowerbed } \\
\text { utilization was made some time } \\
\text { before, which was a source of future } \\
\text { localization advantage }\end{array}$ \\
\hline \multirow{2}{*}{$\begin{array}{l}\text { Dehning i } \\
\text { Stratopoulos } \\
\text { (2003) } \\
\text { - factors of } \\
\text { sustainabil- } \\
\text { ity } \\
\text {-concerned } \\
\text { with project } \\
\text { management }\end{array}$} & $\begin{array}{l}\text { Causal } \\
\text { ambiguity - }\end{array}$ & $\begin{array}{l}\text { Mechanism based on } \\
\text { causal ambiguity - } \\
\text { competitors do not } \\
\text { know, what are the } \\
\text { logical links between } \\
\text { the resource and } \\
\text { abnormal profits }\end{array}$ & $\begin{array}{l}\text { Nobody understands why the } \\
\text { efficiency of the machine is so high } \\
\text { and entrepreneur earns such income }\end{array}$ \\
\hline & Lead-time & $\begin{array}{l}\text { A set of factors, which } \\
\text { determine the time } \\
\text { between the start } \\
\text { of the business and } \\
\text { real reaction of the } \\
\text { competitors }\end{array}$ & $\begin{array}{l}\text { The recipe was possible for } \\
\text { recognition but after long time of the } \\
\text { research and they could lose } \\
\text { a position of leader }\end{array}$ \\
\hline
\end{tabular}




\begin{tabular}{|c|c|c|c|}
\hline 1 & 2 & 3 & 4 \\
\hline \multirow{4}{*}{$\begin{array}{l}\text { Dehning i } \\
\text { Stratopoulos } \\
\text { (2003) } \\
\text { - factors of } \\
\text { sustainabil- } \\
\text { ity } \\
\text {-concerned } \\
\text { with project } \\
\text { management }\end{array}$} & Path dependency & $\begin{array}{l}\text { Decisions made during } \\
\text { early stages of planning } \\
\text { and implementation of } \\
\text { the project have impact } \\
\text { on current choices and } \\
\text { expected returns }\end{array}$ & $\begin{array}{l}\text { The decision about flowerbed } \\
\text { utilization was made some time } \\
\text { before, which was a source of future } \\
\text { localization advantage }\end{array}$ \\
\hline & Role of history & $\begin{array}{l}\text { The unique historical } \\
\text { conditions, which } \\
\text { allowed the firm to } \\
\text { acquire or develop } \\
\text { resources with low } \\
\text { cost. }\end{array}$ & $\begin{array}{l}\text { The offer of preferred bank loan } \\
\text { was only for certain time and under } \\
\text { certain economic conditions }\end{array}$ \\
\hline & $\begin{array}{l}\text { Socially complex } \\
\text { links }\end{array}$ & $\begin{array}{l}\text { Social factors which are } \\
\text { beyond firm control }\end{array}$ & $\begin{array}{l}\text { The relationship with mentor and his } \\
\text { knowledge was a strategic resource, } \\
\text { this resource was protected by } \\
\text { socially complex links, which could } \\
\text { not be recognized and created }\end{array}$ \\
\hline & $\begin{array}{l}\text { Time compression } \\
\text { diseconomies - }\end{array}$ & $\begin{array}{l}\text { They refer to the } \\
\text { resources which are } \\
\text { relatively easy and } \\
\text { cheap for imitation } \\
\text { but they are time- } \\
\text { consuming }\end{array}$ & $\begin{array}{l}\text { The recipe was possible for } \\
\text { recognition but after long time of the } \\
\text { research }\end{array}$ \\
\hline \multirow[t]{3}{*}{$\begin{array}{l}\text { Lepak i wsp. } \\
2007\end{array}$} & $\begin{array}{l}\text { Individual level } \\
\text { mechanisms }\end{array}$ & $\begin{array}{l}\text { Individual condition of } \\
\text { certain people }\end{array}$ & $\begin{array}{l}\text { There was a special role of } \\
\text { entrepreneurial competency in } \\
\text { building informal relations and } \\
\text { socially complex links }\end{array}$ \\
\hline & $\begin{array}{l}\text { Organizational } \\
\text { level mechanisms }\end{array}$ & $\begin{array}{l}\text { The process of } \\
\text { management }\end{array}$ & $\begin{array}{l}\text { Zatrudnienie emerytów, którzy byli } \\
\text { lojalni i strzegli receptury }\end{array}$ \\
\hline & $\begin{array}{l}\text { Social level } \\
\text { mechanisms }\end{array}$ & $\begin{array}{l}\text { The market entry } \\
\text { barriers for competitors } \\
\text { resulted from } \\
\text { possessing by company } \\
\text { certain resources } \\
\text { and beneficial } \\
\text { demand conditions, } \\
\text { appropriate industrial } \\
\text { infrastructure and } \\
\text { competitive markets }\end{array}$ & $\begin{array}{l}\text { The entrepreneur had access to } \\
\text { special localization advantage in } \\
\text { town with certain demand capacity }\end{array}$ \\
\hline
\end{tabular}




\begin{tabular}{|c|c|c|c|}
\hline 1 & 2 & 3 & 4 \\
\hline \multirow[t]{5}{*}{$\begin{array}{l}\text { Hurmelinna- } \\
\text {-Laukkanen } \\
\text { \&Puumala- } \\
\text { inen } 2007 \\
\text { - }\end{array}$} & $\begin{array}{l}\text { The nature of } \\
\text { knowledge }\end{array}$ & $\begin{array}{l}\text { The nature of } \\
\text { knowledge prevents } \\
\text { competitors from } \\
\text { copying }\end{array}$ & Technological knowledge was tacit \\
\hline & Legal rights & $\begin{array}{l}\text { Introduction of patents } \\
\text { and other formal } \\
\text { and legal regulations } \\
\text { prevents competitors } \\
\text { from copying }\end{array}$ & $\begin{array}{l}\text { Formal employment of purchasing } \\
\text { officer included special anex }\end{array}$ \\
\hline & $\begin{array}{l}\text { Human resources } \\
\text { management }\end{array}$ & $\begin{array}{l}\text { Creating contracts } \\
\text { preventing competitors } \\
\text { from copying }\end{array}$ & $\begin{array}{l}\text { Formal employment of purchasing } \\
\text { officer included special anex }\end{array}$ \\
\hline & $\begin{array}{l}\text { Practical and } \\
\text { technical means }\end{array}$ & $\begin{array}{l}\text { Knowledge codification } \\
\text { and technical } \\
\text { limitation. }\end{array}$ & $\begin{array}{l}\text { There was limited access to the } \\
\text { machine }\end{array}$ \\
\hline & Lead time & $\begin{array}{l}\text { A set of factors, which } \\
\text { determine the time } \\
\text { between the start } \\
\text { of the business and } \\
\text { real reaction of the } \\
\text { competitors }\end{array}$ & $\begin{array}{l}\text { The recipe was possible for } \\
\text { recognition but after long time of } \\
\text { the research and they could lose a } \\
\text { position of leader }\end{array}$ \\
\hline
\end{tabular}

\section{Source: own elaboration}

The next part includes the analysis of resource strategic attributes.

The first resource was information about the possibility of machine purchase. The machine had special technical parameters. The value of this information was high because it enabled firm to purchase the machine which gave special efficiency and special, extraordinary earnings (V). Imported machines were very rare in Poland in this period (R). The imitation of this machine was also impossible because competitors were not conscious that this is a source of advantage and it was also the source of nonsubstituability (I, N).

Innovation - additional chilling system increased its efficiency, which was a main reason for gaining extraordinary profit $(\mathrm{V})$. Innovation was tacit and based on rare knowledge (R). Competitors did not have the knowledge, which was a source of efficiency and they did not have a possibility to imitate (I). There was a deficit of modern machines which offer similar efficiency $(\mathrm{N})$.

41 
A preferred bank loan was dedicated to young entrepreneurs (under 35) running businesses in small towns (up to 20000 habitants). It gave the possibility to buy assets, employ people for larger scale than competitors, which gave the entrepreneur an effect of scale $(\mathrm{V})$. The loan granted had a very strict procedure and not everybody could do it (R). Society had no savings which could be a substitute for this loan $(\mathrm{N})$.

Specific localization gave also effect of scale $(\mathrm{V})$. Such a localization was only one in (R) so it could not be copied (I) and there was not other localization giving similar profits of scale $(\mathrm{N})$.

The relationship gave a valuable access to knowledge $(\mathrm{V})$ and the specificity of this relation was rareness (R). A mentor was not a social person and the relation was impossible to copy (I). In the large area there was nobody with such knowledge $(\mathrm{N})$.

The unique technological knowledge of mentor gave the advantage because this technology was never codified (I) and this caused extraordinary profits (V). The source of knowledge was experience in the sector (R). Because of its tacit nature, the knowledge could not be substitutable - competitors did not know a source of success $(\mathrm{N})$.

Loyalty of workers in range of knowledge protection caused high profits for the long term $(\mathrm{V})$. To create such a loyal team is very rare achievement (R). Many social factors supported this process and it was practically impossible to copy (I). There was not a possibility to build another team with the same features or find legal mechanisms to protect knowledge in such a degree(N).

In the next part there is presented an analysis of isolating mechanisms.

The example of simple resource was localization, which was protected by path dependency. The decision of arrangement for flower bed was made in time of early stage of business development. Competitors did not have a similar place for disposal and profits from localization were long-term.

Similarly, the preferred loan was an simple resource and it was protected by the role of history. Competitors had no possibility to follow this resource and gain similar financial power (which was a generic resource) and had no possibility to gain the same effect of scale.

The relation with a mentor and his knowledge was combined resource. The mentor gave this knowledge to the entrepreneur because he trusted him. Until this days the recipe is tacit. The mechanism of advantage protection was socially complex links.

The main bundle of resources consists of localization, recipe, technological innovation and employee loyalty. This bundle was protected by three 
isolating mechanisms. The first was causal ambiguity. Competitors were not able to recognize the causal relation between resources because two of them were tacit. The bundle was protected by the role of history: there were 10 years of good conditions for ice-cream production. There were only two local producers and they were situated in the suburbs and they used machines of low efficiency because only such machines were available this time on the local market. The historical conditions were also lack of higher companies operating in this segment. These conditions caused sustainable resource advantage. The third mechanism was socially complexed links, which caused loyalty for the entrepreneur.

\section{Final remarks}

The aim of this paper was theidentification of categories of isolating mechanisms and the appraisal if the current systems of categorization are sufficient. The case analyzed illustrated all mechanisms and this can be the support for opinion that the list is complete. This case is only one for certain branch. To generalize it, there is a need to compare cases in different sectors or types of organization. The system is also not coherent enough. To make generalization the analyses of another cases are planned.

\section{Summary}

Isolating mechanisms as sustainability factors of resource-based competitive advantage

Strategic resources which fulfill conditions of VRIN generate extraordinary profits for organizations. The possibility of these long-term profits (rents) to achieve can be protected by isolating mechanisms. These mechanisms can be different but the most important are causal ambiguity, lead time, path dependency, the role of history, socially complex links and the time compression diseconomies. These mechanism can be WIM and AIM type (based on willingness or ability). They can be also analyzed on individual, organizational or social levels. The article presents the case study which supports available systems of mechanism categorization.

Keywords: Resource Based View, isolating mechanisms, sustainable competitive advantage, small business. 


\section{Streszczenie}

\section{Mechanizmy izolacji jako czynnik trwałości zasobowej przewagi konkurencyjnej. Studium przypadku}

Zasoby strategiczne, czyli takie, które spełniają warunki VRIN, generują dla przedsiębiorcy zyski wyższe niż u konkurencji. Możliwość długotrwałego osiągania tych wysokich zysków może być zabezpieczona przez mechanizmy izolacji. Do mechanizmów tych należą: niejednoznaczność przyczynowa, czas trwania, ścieżka zależności, uwarunkowania historyczne, powiązania społecznie złożone i dysekonomia kompresji czasu. Mechanizmy te mogą być oparte na woli lub na możliwościach. Mogą także być rozpatrywane na poziomie indywidualnym, organizacyjnym i społecznym. Artykuł przedstawia analizę przypadku ilustrującą systemy kategoryzacji tych mechanizmów.

\section{Stowa}

kluczowe: ujecie zasobowe, mechanizmy izolacji, trwała przewaga konkurencyjna, mate przedsiębiorstwo.

\section{References}

1. Alvarez S. A., Barney J.B. (2004), Organizing rent generation and appropriation: toward a theory of the entrepreneurial firm, "Journal of Business Venturing", vol. 19, no. 5, pp. 621-635.

2. Ambrosini V., Bowman C. (2010), The Impact of Causal Ambiguity on Competitive Advantage and Rent Appropriation, "British Journal of Management", vol. 21, pp. 939-95.

3. Bach S.B., Jidge W.Q., Dean T.J. (2008), A Knowledge-based View of IPO Success: Superior Knowledge, Isolating Mechanisms, and the Creation of Market Value, "Journal of Managerial Issues", vol. 20, no. 4, pp. 507-525.

4. Barney J. (1991), Firm resources and sustained competitive advantage, „Journal of Management", vol. 17, no. 1, pp. 99-120.

5. Barney J. B., Clark D. N. (2007), Resource-Based Theory: Creating and Sustaining Competitive Advantage, Oxford University Press, Oxford.

6. Bowman C., Ambrosini V. (2000), Value Creation Versus Value Capture: Towards a Coherent Definition of Value in Strategy, „British Journal of Management", Vol. 11, s. 1-15.

7. Bryler M, Coff, R.W. (2003), Dynamic capabilities, social capital and rent appropriation: ties that split pies, "Strategic Management Journal" vol. 24, s. 677-686. 
8. Burt R. S. (1992), Structural holes: The social structure of competition, Harvard University Press, Cambridge.

9. Chacar A. S., Coff R. (2000), Deconstructing a knowledge-based advantage: rent generation, rent appropriation and performance in investment banking, w: Hitt M. i wsp. (2000), Winning Strategies in Deconstructing World, John Wiley, Nowy Jork,

10. Coff R.W. (2010), The coevolution of rent appropriation and capability development, "Strategic Management Journal”, vol. 31, s. 711-730.

11. Coff R.W. (2003), Insider trading a vehicle to appropriate rent in RED, "Strategic management Journal", vol. 24, s. 183-190.

12. Coff R. W., (1999), When competitive advantage doesn't lead to performance: resource-based theory and the stakeholder bargaining power, "Organization Science", vol. 10, s. 119-133.

13. Czakon W. (2011), Zastosowanie studiów przypadków w badaniach nauk o zarzadzaniu, w: W. Czakon (red.) Podstawy metodologii badan w naukach o zarządzaniu, Oficyna Wolters Kluwer business, Warszawa, pp. 45-63

14. Dehning B., Stratopoulos T. (2003), Determinants of a sustainable competitive advantage due to an IT-enabled strategy, "Journal of Strategic Information Systems", vol. 12, no. 1, pp. 7-28.

15. Hurmelinna-Laukkanen P., Puumalainen K. (2008), Nature and dynamics of appropriability: strategies for appropriating returns on innovation, "R\&D Management", vol. 37, pp. 95-112.

16. Hurmelinna-Laukkanen P., Puumalainen K. (2007), Formation of the appropriability regime: Strategic and practical considerations, „Innovation: Management, Policy \& Practice", vol. 9, no 1, pp. 2-13

17. King, A. W. and C. P. Zeithaml (2001) Competencies and firm performance: examining the causal ambiguity paradox, "Strategic Management Journal”, vol. 22, no. 1. pp. 75-99.

18. Lepak D.P., Smith K.G., Taylor M.S. (2007), Value Creation and Value Capture. A Multilevel Perspective, "Academy of Management Review”, vol. 32, no. 1, pp. 180-194.

19. Lim J-H., Stratopoulos T.C., Virjanto T. S. (2012), Path Dependence of Dynamic Information Technology Capability: An Empirical Investigation, "Journal of Management Information Systems", Vol. 28, No. 3, pp. 45-84/

20. Madhok A., Li S., Priem R. L., (2010), The resource-based view revisited: Comparative firm advantage, willingness-based isolating mechanisms and competitive heterogeneity, "European Management Review”, vol. 7, no. 2, pp. 91-100.

21. Mazur K. (2011), Tworzenie i przywłaszczanie wartości. Perspektywa relacji: pracownik - organizacja, Oficyna Wydawnicza Uniwersytetu Zielonogórskiego, Zielona Góra. 
22. Porter M. (1990), The competitive advantage of nations, Free Press, Nowy Jork.

23. Rumelt R. P. (1987), The Competitive Challenge: Strategies for Industrial Innovation and Renewal, Ed. D. J. Teece., Ballinger, Cambridge, pp. 137-158.

24. Rumelt R. (1984), Toward a strategic theory of the firm. In R. Lamb (ed.), Competitive Strategic Management, pp. 556-570. Englewood Cliffs, NJ: Prentice Hall.

25. Shaffer G. (1991), Capturing Strategic Rent: Full-Line Forcing, Brand Discounts, Aggregate Rebates, And Maximum Resale Price Maintenance, "Journal of Industrial Economics" vol. 39, no. 5, pp. 557-575.

26. Sirmon D. G., Hitt M. A., Ireland R. D. (2007), Managing firm resources in dynamic environments to create value: Looking inside the black box, "Academy of Management Review", vol. 32, no. 1, pp. 273-292.

27. Stabell C.B., Fjeldstad Ø.D. (1998), Configuring value for competitive advantage: on chains, shops, and networks, "Strategic Management Journal", vol. 19, s. 413-437.

28. http://www.kignet.pl/pl/platforma_inicjatyw_klastrowych/dzki_ klaster_budowlany_twj_dom.html 